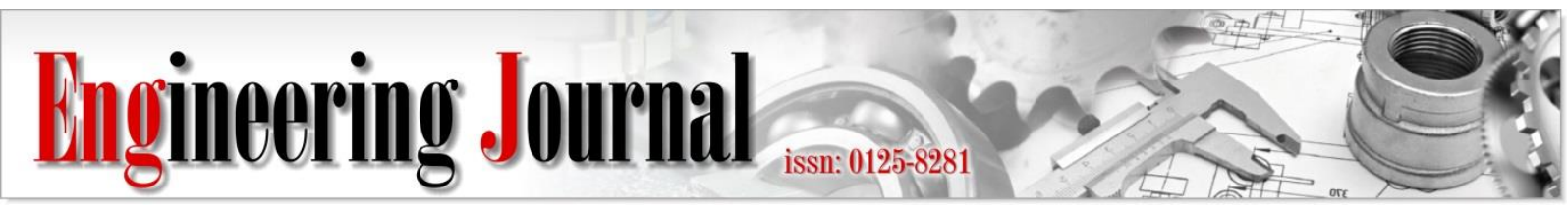

Article

\title{
Self-healing Behavior of Expansive Mortars with Fly Ash and Bottom Ash
}

\author{
Nghia D. Tran ${ }^{1, a}$, Warangkana Saengsoy ${ }^{2, b^{*}}$, and Somnuk Tangtermsiriku1 ${ }^{1, \mathrm{c}}$ \\ 1 School of Civil Engineering and Technology, Sirindhorn International Institute of Technology (SIIT), \\ Thammasat University, Thailand \\ 2 Construction and Maintenance Technology Research Center (CONTEC), School of Civil Engineering and \\ Technology, Sirindhorn International Institute of Technology (SIIT), Thammasat University, Thailand \\ E-mail: adainghia.mb@gmail.com, b, ${ }^{*}$ warangkana@siit.tu.ac.th (Corresponding author), \\ csomnuk@siit.tu.ac.th
}

\begin{abstract}
In this paper, the effectiveness of fly ash (FA) and bottom ash (BA) on the selfhealing $(\mathrm{S}-\mathrm{H})$ behavior of expansive concrete was experimentally investigated by using the crack closing ratio and water flow rate as indicators of the self-healing ability. To heal cracks that may be caused by shrinkage, high $\mathrm{CaO}_{-} \mathrm{SO}_{3}$-free lime fly ash (FAB), high $\mathrm{CaO}$ fly ash (FAA), and low $\mathrm{CaO}$ fly ash (FAR), and one type of expansive additive were used as the partial binder replacement materials. A pre-soaked bottom ash with high water retainability was used as a water-providing agent for the internal curing (IC) technique, to reduce shrinkage and enhance long-term hydration. Pre-cracked mortar samples were prepared in a disc shape with a fixed crack width of $0.1 \mathrm{~mm}$. After crack creation, the crack width ratio and water flow rate were monitored every 7 days for 3 months. It was observed that expansive mortars with 30\% fly ash showed significant improvement in the self-healing ability when compared to the non-fly ash mortar. The use of $10 \%$ bottom ash showed enhanced self-healing ability in expansive mortar. Moreover, using both fly ash and bottom ash showed significant improvement in the self-healing behavior.
\end{abstract}

Keywords: Self-healing, internal curing, expansive additive, fly ash, bottom ash.

ENGINEERING JOURNAL Volume 25 Issue 2

Received 17 January 2020

Accepted 29 January 2021

Published 28 February 2021

Online at https:/ / engj.org/

DOI:10.4186/ej.2021.25.2.121 


\section{Introduction}

Self-healing (S-H) is a desirable ability for concrete that helps eliminate shrinkage cracks. With this ability, concrete can heal damage (mainly cracks) by itself without any external course of action. In much research, the S-H ability of concrete was studied and mentioned [1-7]. Recently, various alternative cementitious materials have been investigated, to clarify their effects on the selfhealing ability of concrete $[1,3,4,5]$.

The S-H behavior of cementitious based materials with calcium sulfoaluminate based expansive additives was studied by Sisomphon et al. [1], Hosoda et al. [2], and Kishi et al. [3]. Jaroenratanapirom and Sahamitmongkol [4] used fly ash, silica fume, and crystalline admixtures as different cement replacement materials to study the self-healing potential of mortars.

Favorable conditions for the self-healing ability of concrete have been studied. Qian et al. [5] confirmed that submerging samples in water is better at improving the self-healing ability of concrete when compared to air curing. The behavior of water flow rates of pre-cracked concrete samples was measured by Edvardsen [6]. It was observed that the water flow rates of pre-crack concrete samples decreased with time, meaning that concrete cracks were healed by themselves. Reinhardt and Joose [7] investigated the relationship between self-healing behavior and water permeability of cracked concrete. Their results showed that the flow rate decreased due to self-healing, and self-healing efficiency depended on crack width and temperature.

Internal curing is an active curing method to promote the self-healing capability of concrete. Internal curing is defined as "supplying water throughout a placed cementitious mixture using reservoirs, via an internal moisture supplying material such as pre-wetted lightweight aggregates, that readily release water as needed for hydration or to replace moisture loss due to evaporation or self-desiccation" [8]. By providing internal curing (IC), shrinkage can be reduced, and the strength and some durability properties of concrete can be enhanced. A variety of materials can be used for internal curing, including superabsorbent polymers, pre-wetted crushed returned concrete fines, pre-wetted lightweight aggregates, and pre-wetted wood fibers.

Bottom ash (BA) is a product of coal power plants. It has been used as a landfill material or dumped. As a porous material with very low cost and high waterretaining properties, BA can be used as an IC material by partially replacing fine aggregate in concrete. It was confirmed that $10 \% \mathrm{BA}$ replacement of fine aggregate showed positive effects on concrete $[9,10,11]$. In addition, the compressive strength of OPC concrete [10] and self-compacting concrete [9] increased with the use of BA in a proper amount. It was reported that using BA can help to eliminate the shrinkage cracking of concrete $[12,13]$. Sutthiwaree et al. [11] investigated the effects of $\mathrm{BA}$ on the durability of expansive concrete. Their results showed that it is possible to reduce the risk of shrinkage- cracking at an early age by using BA as the internal curing material. They found that BA could increase the expansion of expansive concrete. The use of internally cured concrete was shown to reduce cracking in field structures [14]. An important property of $\mathrm{BA}$ is water retainability (WR), and this ability of BA particles to hold water can be evaluated. A method to determine the WR of BA was proposed by Kasemchaisiri and Tangtermsirikul [9], which was later modified by Lathsoulin et al. [15]. In this study, the method to obtain the WR of BA was developed by Nguyen et al. [25], based on the study of Lathsoulin et al. [15].

However, the effects of bottom ash and fly ash with different contents of calcium oxide, free lime, and sulfur trioxide on the self-healing behavior of cement-based materials has not been studied. The objectives of this study are to investigate the effectiveness of three types of fly ash (having different chemical compositions) and a bottom ash on the self-healing ability of expansive mortars. Moreover, this study aims to develop the practical application of $\mathrm{BA}$ as an IC agent, together with the use of fly ash, especially with excessive free lime and $\mathrm{SO}_{3}$ contents. BA can eliminate shrinkage cracking and promote the self-healing ability of concrete, especially expansive concrete. Therefore, this paper studies the selfhealing ability of mortars with an expansive additive and three types of fly ash and a bottom ash. This study uses the surface crack closing rate and water flow rate as the evaluation criteria for the experimental determination of the degree of self-healing.

\section{Experimental Program}

\subsection{Materials and Specimens}

In this study, OPC type I cement, an expansive additive (EA) and three types of fly ash (FA) (fly ash type A: high $\mathrm{CaO}$ fly ash, type $\mathrm{B}$ : high $\mathrm{CaO}-\mathrm{SO}_{3}$-free lime fly ash, and type $\mathrm{R}$ : low $\mathrm{CaO}$ fly ash) were used as binders. Chemical compositions and physical properties of the binders are given in Table 1. A river sand with a specific gravity of 2.58 at SSD conditions and a water absorption of $1.07 \%$ was used as the fine aggregate. A bottom ash (BA) with a specific gravity of 1.83 and a water retainability (WR) of $36.61 \%$ was used as the partial fine aggregate replacing material. The water retainability of the BA was measured (developed by Nguyen et al. [25]) in the same way as Lathsoulin et al. [15], but with a longer vibrating time to measure the WR. To measure the WR, BA that passed sieve No. 4 was immerged in water for 72 hours before being drained for 30 minutes to remove the free water. After that, a PVC pipe was filled with 3 layers of BA. Then, each layer was compacted 30 times by a rubber hammer on the side surface of the PVC pipe. After covering the top of the PVC pipe to prevent evaporation of water, the PVC pipe was vibrated for 60 minutes. The excess water in the BA was removed while the retained water was kept by the $\mathrm{BA}$ particles. The water retainability of the $\mathrm{BA}$ was 
obtained from the moisture content of the BA sample that was collected from the top $3 \mathrm{~cm}$ of the tested sample

To prepare cracked specimens, mortar specimens were prepared in a disc shape with $100 \mathrm{~mm}$ of diameter and $25 \mathrm{~mm}$ of thickness. A crack of $0.1 \mathrm{~mm}$ in width was introduced into each specimen at 3 days of age. Figure 1 illustrates a photo, drawings, and dimensions of a specimen for the surface crack closing rate test. For the water permeability test, samples were prepared in the same manner as that of the crack closing rate specimens but were coated with an epoxy layer at the round side (see Fig. 2(a)).

To investigate the effects of FA on the self-healing behavior, samples were cured in water. Different mixtures were cured in separate containers, and the water was renewed after every measurement. To clearly observe the effects of BA (to provide internal curing) on the $\mathrm{S}-\mathrm{H}$ behavior, specimens were air-cured.

\subsection{Experimental Method}

A crack was created on each mortar specimen by the splitting method at the age of 3 days after casting. A stainless ring was used to control for a constant surface crack width of $0.1 \mathrm{~mm}$ before curing. A digital microscope with computer software was applied to observe and measure the surface crack width. Crack widths were measured at 5 marked major points along the crack line, as illustrated in Fig. 1(b) and Fig. 1(c) (each major point contained 4 minor measured points, therefore, there were 20 minor measured points in 1 sample). The distance between each pair of measured major points was $20 \mathrm{~mm}$. Initial crack widths were monitored at 3 days of age. Then, the time-dependent crack widths were measured at $7,14,21,28,35,42,49$, 56, 63, 70, 77, 84, and 91 days of age. After having recorded the crack width of the samples at each age, the crack-closing ratio was computed. The crack-closing ratio quantitatively indicates the decrease of crack width of the sample at a specific age.

To confirm the self-healing performance of mortars, the water permeability test was performed simultaneously with the surface crack closing rate test. The water permeability test was carried out according to the Western Australian WA625.1 standard [16] (based on DIN 1048 [17]). Samples were prepared in the same fashion as that of the crack closing rate test. After introducing a crack width of $0.1 \mathrm{~mm}$, the specimens were coated with an epoxy layer of $25 \mathrm{~mm}$ in thickness and 25 $\mathrm{mm}$ in width at the round side (Fig. 2(a)), and then cured in air or water. The samples were immersed in water to maintain saturated conditions before being installed in the permeability cell and applying water pressure (Fig. 2(b)). After that, a water cylinder column $(1500 \mathrm{~mm}$ in height, $8 \mathrm{~mm}$ in diameter) was installed, and 0.5 Bar of water pressure was constantly applied to each specimen until the height of water in the column dropped from the $50 \mathrm{~cm}$ point to the $0 \mathrm{~cm}$ point. The time for the water column to drop from the $50 \mathrm{~cm}$ point to the $0 \mathrm{~cm}$ point was recorded, to calculate the flow rate of water by using Eq. (1). The water permeability test device is shown in Fig. 3. The water flow rate $\left(\mathrm{Q}_{(\mathrm{t})}\right)$ is defined as

$$
Q_{(t)}=\frac{V_{w}}{\Delta_{t}}
$$

where $Q_{(t)}$ is the water flow rate $\left(\mathrm{m}^{3} / \mathrm{s}\right)$, and $V_{w}$ is the volume of water in $\mathrm{m}^{3}$ flowing through the crack within a period of time $\Delta_{\mathrm{t}}$ in seconds.

Table 1. Properties of binders.

\begin{tabular}{lccccr}
\hline $\begin{array}{c}\text { Chemical } \\
\text { Compositions } \\
\text { and Physical } \\
\begin{array}{c}\text { Properties } \\
\text { (\% by }\end{array}\end{array}$ & OPC & EA & FAA & FAB & FAR \\
weight) & & & & & \\
$\mathrm{SiO}_{2}$ & 19.70 & 2.45 & 37.09 & 26.61 & 61.09 \\
$\mathrm{Al}_{2} \mathrm{O}_{3}$ & 5.19 & 5.21 & 19.69 & 13.60 & 20.35 \\
$\mathrm{Fe}_{2} \mathrm{O}_{3}$ & 3.34 & 0.19 & 14.18 & 18.34 & 5.2 \\
$\mathrm{CaO}$ & 64.80 & 61.85 & 19.36 & 24.97 & 2.32 \\
$\mathrm{MgO}$ & 1.20 & 0.60 & 2.32 & 2.33 & 1.35 \\
$\mathrm{SO}$ & 2.54 & 25.80 & 3.24 & 8.53 & 0.28 \\
$\mathrm{Na}_{2} \mathrm{O}$ & 0.16 & - & 0.35 & 1.75 & 0.79 \\
$\mathrm{~K}_{2} \mathrm{O}$ & 0.44 & - & 2.92 & 1.77 & 1.36 \\
$\mathrm{Free} \mathrm{lime}_{\mathrm{LOI}}^{\mathrm{LO}}$ & 0.87 & 23.61 & 2.36 & 3.93 & 0.03 \\
$\mathrm{Specific} \mathrm{gravity}$ & 2.10 & 3.70 & 0.01 & 0.53 & 5.68 \\
$\mathrm{Blaine}$ fineness & 3100 & 2.94 & 2.20 & 2.57 & 2.11 \\
(cm 2 g) & 3100 & - & 2790 & 2820 & 3400 \\
\hline
\end{tabular}

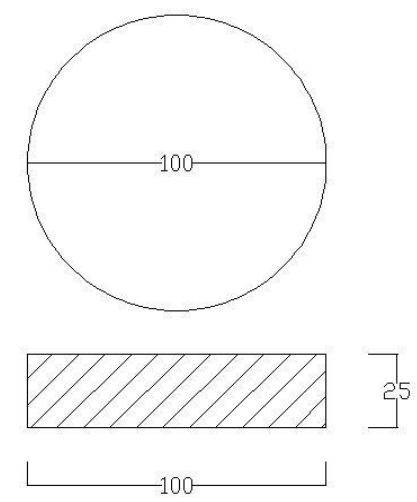

(a)

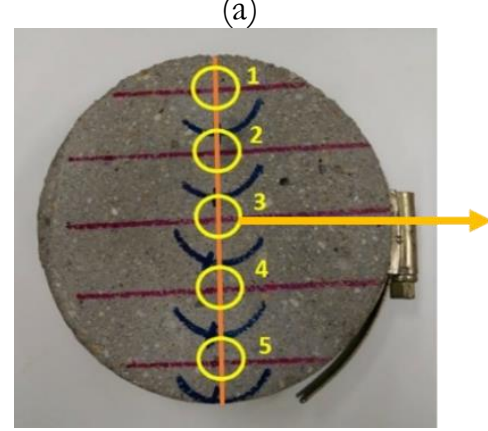

(c)

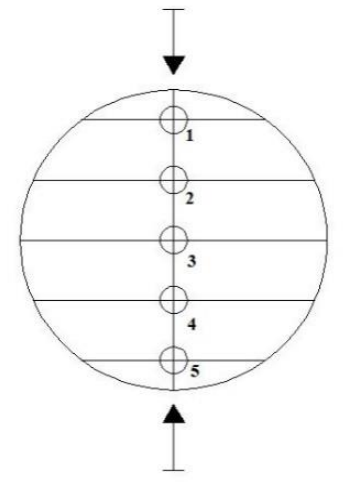

(b)

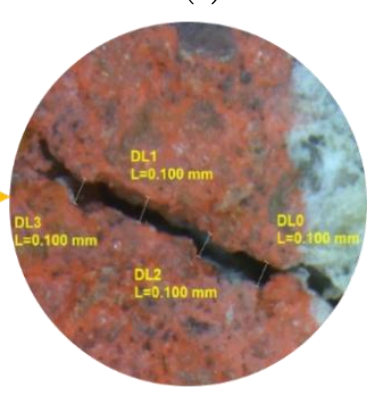

(d)
Fig. 1. Mortar specimen for crack closing rate measurement, (a) Dimension of the specimen (mm), (b) Creating and marking cracks, (c) Specimen with a stainless ring clamp, (d) Four minor points in one marked major point. 


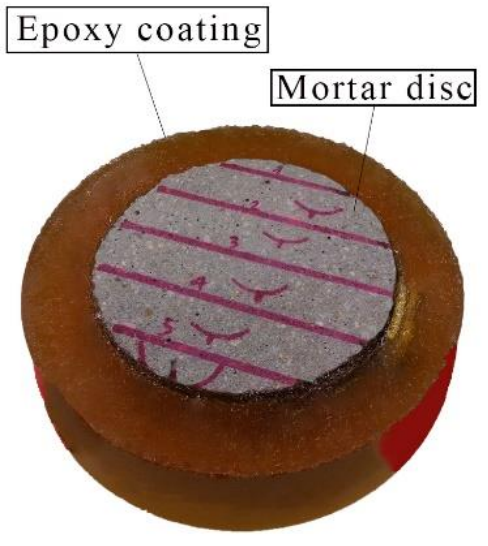

(a) Water permeability specimen

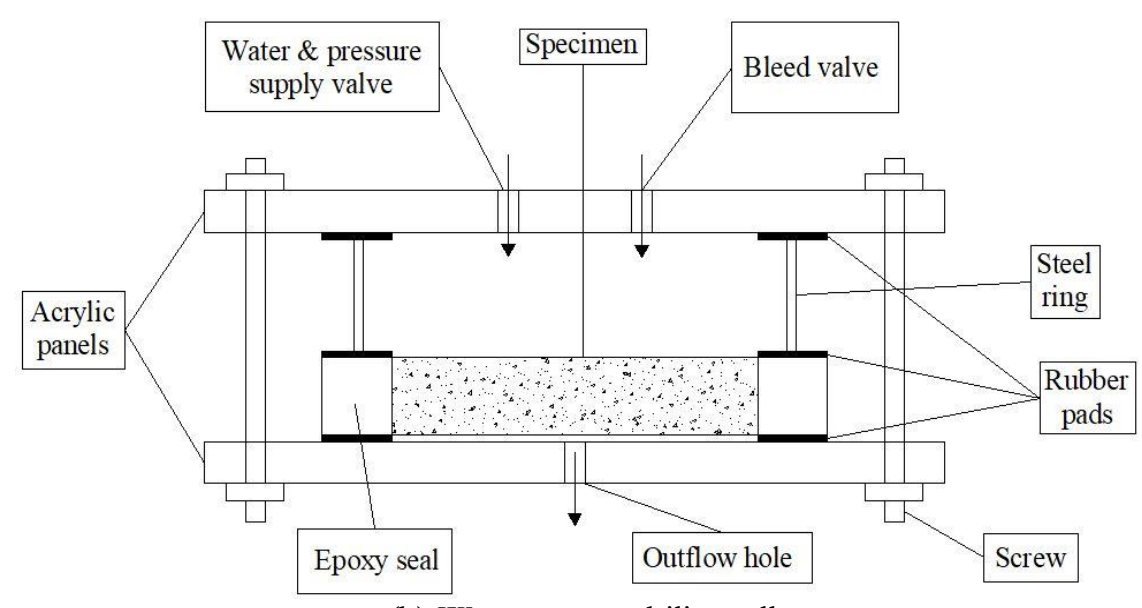

(b) Water permeability cell

Fig. 2. Specimen preparation and setup of permeability test.

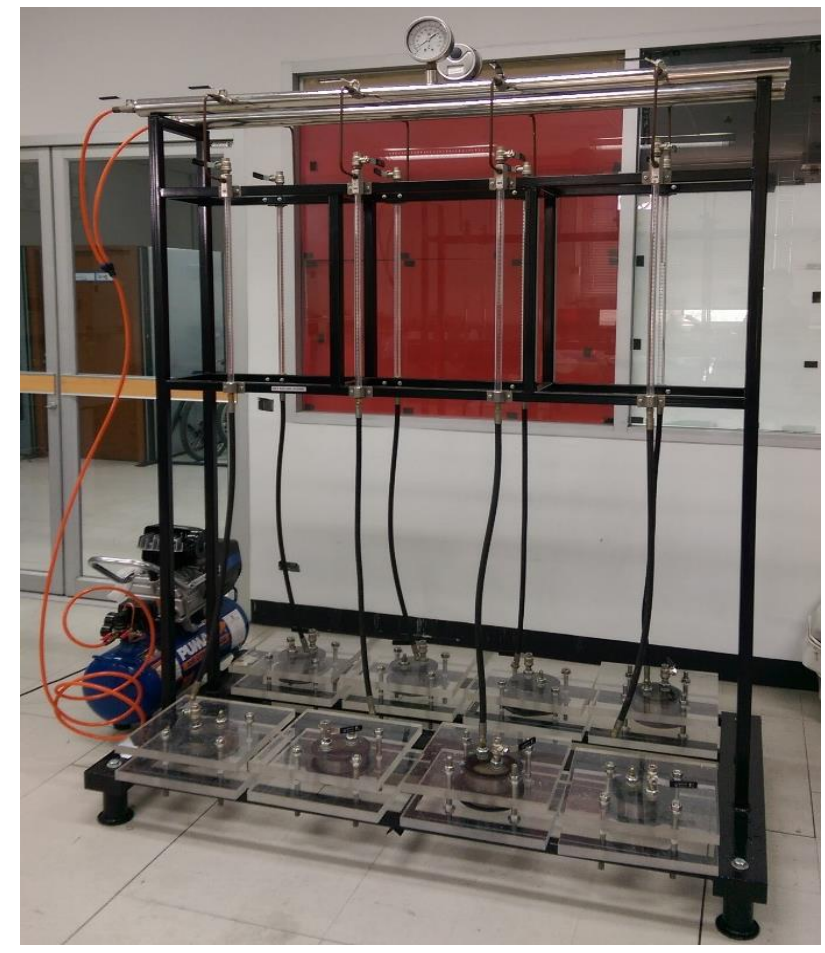

Fig. 3. Water permeability testing device.

\subsection{Mix Proportions}

Various mixtures of mortars were studied as follows: OPC type I with and without $10 \%$ of BA to replace fine aggregate, $\mathrm{OPC}+6 \%$ expansive agent $(\mathrm{EA})$ with and without $10 \% \mathrm{BA}, \mathrm{OPC}+30 \%$ fly ash type A, OPC $+30 \%$ fly ash type R, OPC $+30 \%$ fly ash type B with and without $10 \% \mathrm{BA}$, and $\mathrm{OPC}+6 \% \mathrm{EA}+30 \%$ fly ash type $\mathrm{B}$ with and without $10 \% \mathrm{BA}$. All these mixtures were prepared with a water to binder ratio of 0.45 . A summary of the tested mix proportions is given in Table 2.

\section{Result and Discussion}

The effects of FA and BA on the self-healing ability of mortar were investigated by using the crack closing ratio and water flow rate as indicators. While the crack closing ratio indicates $\mathrm{S}-\mathrm{H}$ behavior on the surface, the water flow rate shows the overall healing in the cracks.

The surface crack closing ratio $\left(\beta_{(t)}\right)$ quantitatively demonstrates changes in the surface crack width at a specific time t. The crack closing ratio $\left(\beta_{(t)}\right)$ is defined as

$$
\beta_{(t)}=\left(1-\frac{C W_{(t)}}{C W_{i}}\right) \cdot 100 \%
$$

Table 2. Mix proportions of the tested mortars.

\begin{tabular}{|c|c|c|c|c|c|c|c|c|c|c|}
\hline \multirow{2}{*}{ Mix ID } & \multirow{2}{*}{$\begin{array}{c}\text { OPC } \\
\text { type I } \\
\left(\mathrm{kg} / \mathrm{m}^{3}\right)\end{array}$} & \multirow{2}{*}{$\underset{\left(\mathrm{kg} / \mathrm{m}^{3}\right)}{\text { EA }}$} & \multicolumn{3}{|c|}{$\begin{array}{l}\text { Fly ash } \\
\left(\mathrm{kg} / \mathrm{m}^{3}\right)\end{array}$} & \multirow{2}{*}{$\begin{array}{c}\text { Water } \\
\left(\mathrm{kg} / \mathrm{m}^{3}\right)\end{array}$} & \multicolumn{2}{|c|}{$\begin{array}{l}\text { Fine aggregate } \\
\left(\mathrm{kg} / \mathrm{m}^{3}\right)\end{array}$} & \multicolumn{2}{|c|}{$\begin{array}{l}\text { Curing } \\
\text { conditions }\end{array}$} \\
\hline & & & FAA & FAB & FAR & & Sand & BA & Water & Air \\
\hline OPC & 534.54 & - & - & - & - & 240.54 & $1,469.99$ & - & $\bullet$ & - \\
\hline OPCBA10 & 534.54 & - & - & - & - & 240.54 & $1,322.99$ & 145.29 & & - \\
\hline EA6 & 502.10 & 32.05 & - & - & - & 240.36 & $1,468.90$ & - & - & - \\
\hline EA6BA10 & 502.10 & 32.05 & - & - & - & 240.36 & $1,322.01$ & 145.18 & & - \\
\hline FAA30 & 366.09 & - & 156.9 & - & - & 235.34 & $1,438.21$ & - & - & \\
\hline FAR30 & 364.84 & - & - & - & 156.36 & 234.54 & $1,433.29$ & - & - & \\
\hline FAB30 & 369.84 & - & - & 158.5 & - & 237.76 & $1,452.95$ & - & - & - \\
\hline FAB30BA10 & 369.84 & - & - & 158.5 & - & 237.76 & $1,307.66$ & 143.61 & & - \\
\hline EA6FAB30 & 337.89 & 31.68 & - & 158.39 & - & 237.58 & $1,451.89$ & - & - & - \\
\hline EA6FAB30BA10 & 337.89 & 31.68 & - & 158.39 & - & 237.58 & $1,306.70$ & 143.50 & & - \\
\hline
\end{tabular}


where, $C W_{i}$ is the initial crack width $(\mathrm{mm})$ and $C W_{(t)}$ is crack width after $\mathrm{t}$ days of age $(\mathrm{mm})$. Therefore, $\beta_{(t)}=0 \%$ means no healing while $\beta_{(\mathrm{t})}=100 \%$ means complete healing.

The water flow rate indicates the amount of water that can flow through the crack during a period of time under constant pressure. The smaller the water flow rate, the smaller the crack width. The water flow rate is calculated by using Eq. (1) in Section 2.2.

\subsection{Effects of Expansive Additive and Fly Ash}

The crack closing ratio and the water flow rate were measured at different ages of pre-cracked samples with an initial surface crack width of $0.1 \mathrm{~mm}$. The effects of expansive additive and fly ashes on the self-healing ability are shown in Fig. 4 and Fig. 5. The crack closing ratios of OPC, EA6, FAB30, and EA6FAB30 samples are illustrated in Fig. 4(a), while the water flow rates of these samples are shown in Fig. 5(a). The crack closing ratios and water flow rates of the OPC sample and samples with different types of fly ash are shown in Fig. 4(b) and Fig. 5(b).

The expansive additive can enhance the self-healing behavior of mortar, which is shown in Fig. 4(a) and Fig. 5(a). In Fig. 4(a), the crack closing ratio of both OPC mortar and fly ash mortar with EA are higher than those of the mortars without EA at all tested ages. Figure 5(a) illustrates the water flow rate of mortars with and without expansive additive. It shows that the water flow rates of OPC and fly ash mortars with EA are smaller than those of the non-EA mortars. This means that the self-healing ability of EA mortars is better than that of the non-EA mortars.

The effects of fly ash on the self-healing ability of mortars are shown in Fig. 4 and Fig. 5. Figure 4(a) and Figure 5(a) show the effects of fly ash on the self-healing ability. The crack closing ratios of OPC mortar and expansive mortars with and without fly ash are shown in Fig. 4(a). It illustrates that an expansive agent can remarkably increase the crack closing ratio (the EA6 sample completely heals crack within 35 days). The crack closing ratio is significantly improved when using fly ash in the expansive mortar (EA6FAB30), leading to complete crack sealing in 28 days. The same tendency of FA on the S-H ability is confirmed by flow rate results, as shown in Fig. 5(a).

Figure 4(b) shows the surface crack closing ratios of pre-cracked mortars with an initial surface crack width of $0.1 \mathrm{~mm}$, made from different types of fly ash (FAA, FAB, and FAR). The results show that mortar with FAB completely closes the crack within 77 days. The crack of the specimen with FAA is fully healed after 91 days, while the FAR sample cannot completely heal the crack in up to 91 days. In addition, it is observed that the use of fly ashes in mortar samples significantly enhances the surface crack closing ability, compared to the non-fly ash sample (OPC). The effects of different types of fly ash on the self-healing ability are also demonstrated by the water flow rates. Figure 5(b) shows the water flow rate with time for OPC mortar and mortars with different types of fly ash. The graph shows the same tendency as the crack closing ratios. Fly ash mortars show better performance than the OPC mortar. Among different mixtures, FAB30 shows the shortest healing time, compared to FAA30 and FAR30.

In this study, a hypothesis for the mechanism of the self-healing ability of mortar is proposed. Crack filling by ettringite (product) is considered as the major mechanism of the self-healing ability. In general, ettringite, calcium hydroxide, and other products can be found inside the sample. When they occur at the crack area, they participate in the self-healing ability by filling the crack (see Fig. 6). In this study, ettringite is formed as a product of the hydration reaction at an early age. It is also formed by the reaction of fly ash, especially by the fly ash with high $\mathrm{SO}_{3}$ and free lime contents. For regular fly ash with low $\mathrm{SO}_{3}$ and free lime contents, the longterm pozzolanic reaction can also help in producing pozzolanic products to fill the cracks. In contrast, EA may not help long-term cracks as the reaction of EA stops in about 3-7 days, especially when there is no fly ash in the EA mixture. A. Hosoda et al. [20] showed that ettringite and calcite were found to fill 50 to $100 \mu \mathrm{m}$ and $200 \mu \mathrm{m}$ cracks of 34-year PC concrete poles by image analysis (RGB method). It was observed that ettringite existed along the crack and at the interface area of the crack and the matrix. The main components of ettringite are $\mathrm{Ca}^{2+}, \mathrm{Al}^{3+}$, and $\mathrm{SO}_{4}{ }^{2-}$. When cracks occur in the matrix, the cement paste matrix is the source for providing these constituent elements to generate ettringite. Moreover, T. Danner et al. [21] also confirmed that ettringite formation was one of two major mechanisms of the self-healing ability of cracks in concrete exposed for 25 years to marine conditions. In Fig. 7, N. Thuy et al. [22] used XRD analysis for the mineralogical investigation of paste specimens at an age of 7 days, using the same materials (OPC, EA, FA), but slightly different mixes from those tested in this study. Ettringite was observed in the FA paste, EA paste, and EA paste using FA, except for the OPC paste. This explains the self-healing ability of EA mortars in that the self-healing ability of FA mortars and EA mortars with FA is significantly improved when compared to OPC mortar. Their samples were prepared with the same materials as those of this study. The mix proportions were similar except for the amount of EA used in the expansive mortar with fly ash $(5 \%$ EA was used in their study instead of $6 \%$ ). However, the tendency of the result is expected to be similar, except that the ettringite amount of EA6 should be higher than that in EA5. 


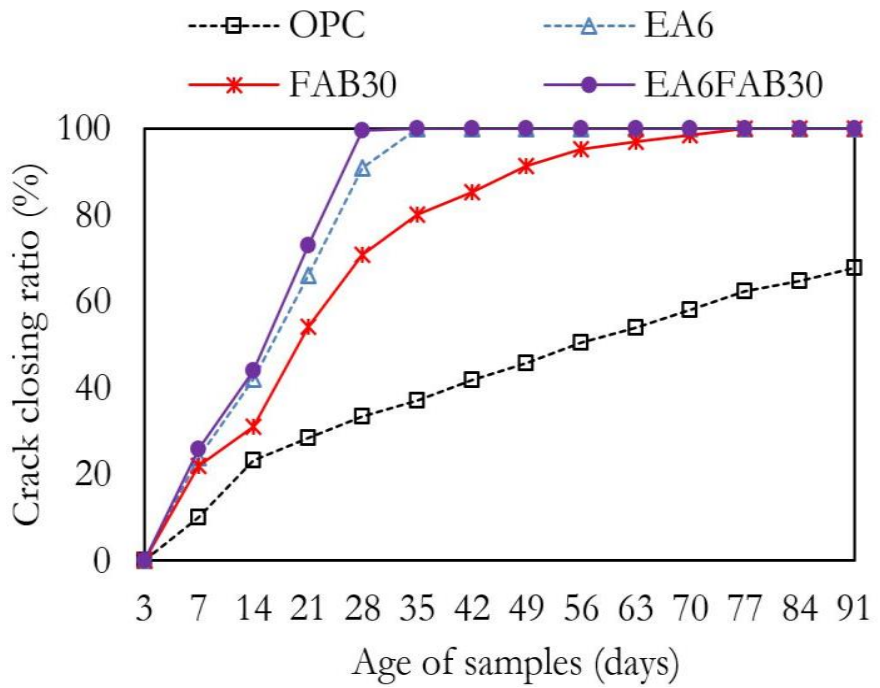

(a) OPC mortar and expansive mortar with and without fly ash

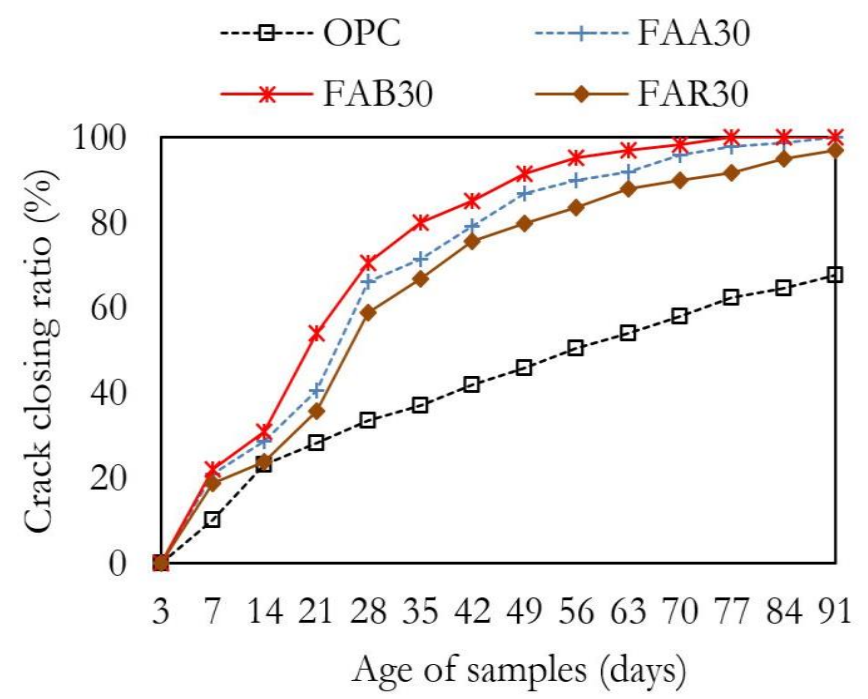

(b) OPC mortar, and mortar with different types of fly ash

Fig. 4. Crack closing ratio of mortar (in water curing conditions).

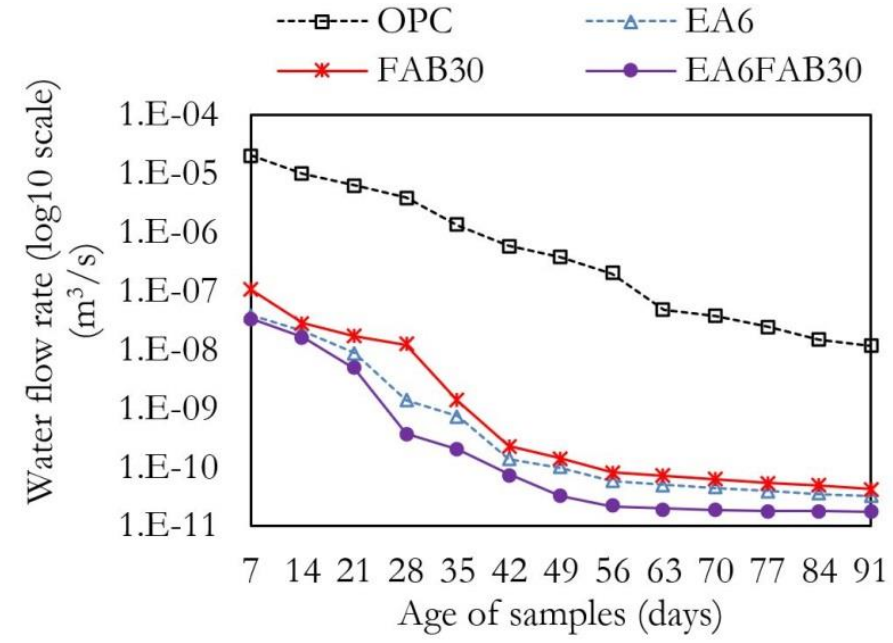

(a) OPC mortar, expansive mortar with and without fly ash

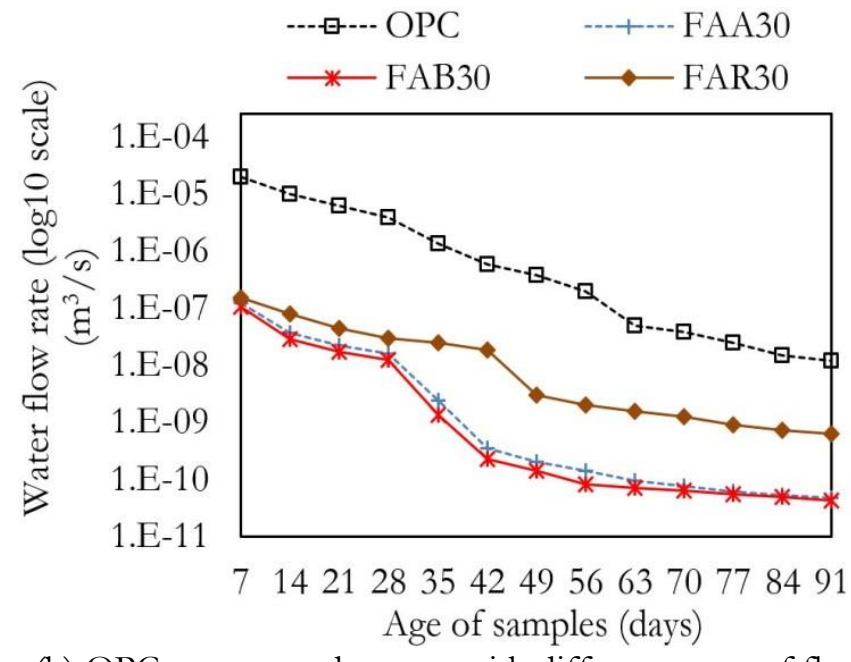

(b) OPC mortar, and mortar with different types of fly ash

Fig. 5. Water flow rate of mortars (in water curing conditions).

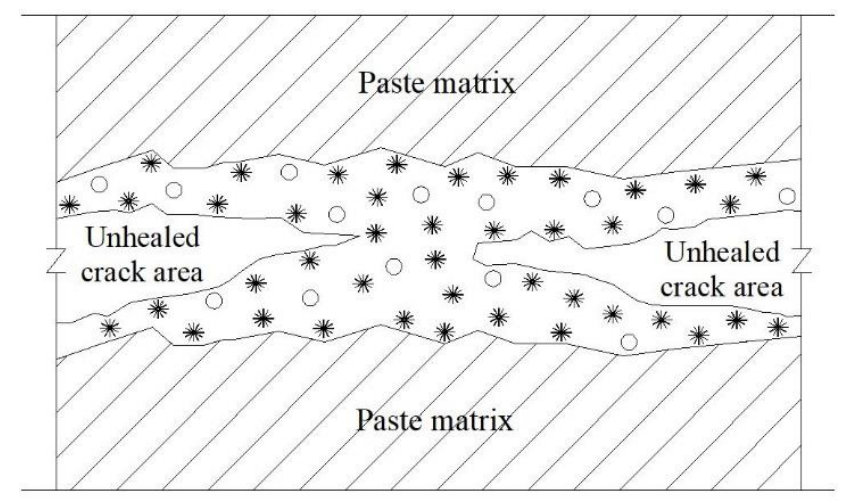

* Ettringite Others (Portlandite, Calcite, etc.)

Fig. 6. Self-closing of crack due to the filling by expansive products.

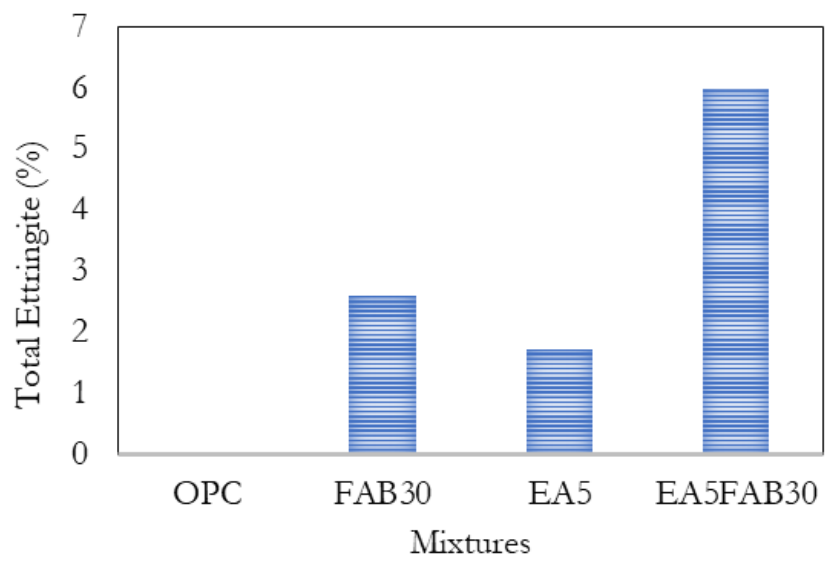

Fig. 7. Results of ettringite amount in different mixtures. 


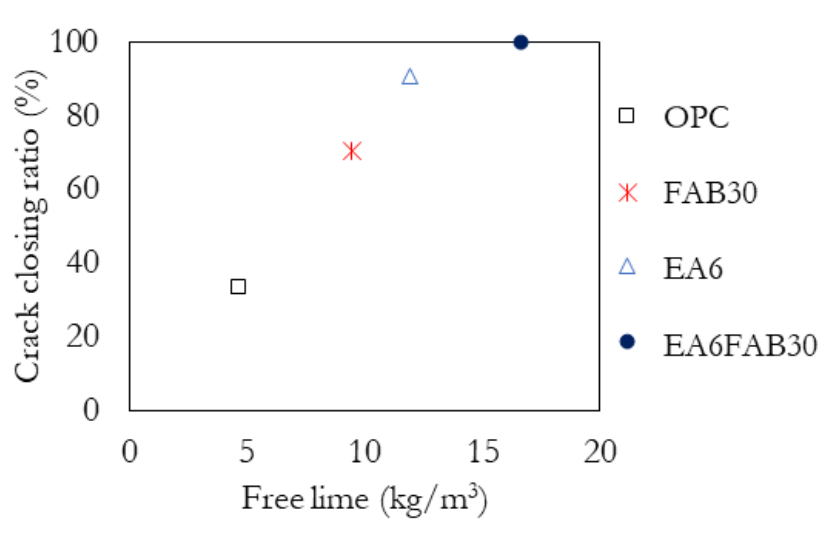

a) Relationship between free lime content and the crack closing ratio of the tested mixtures

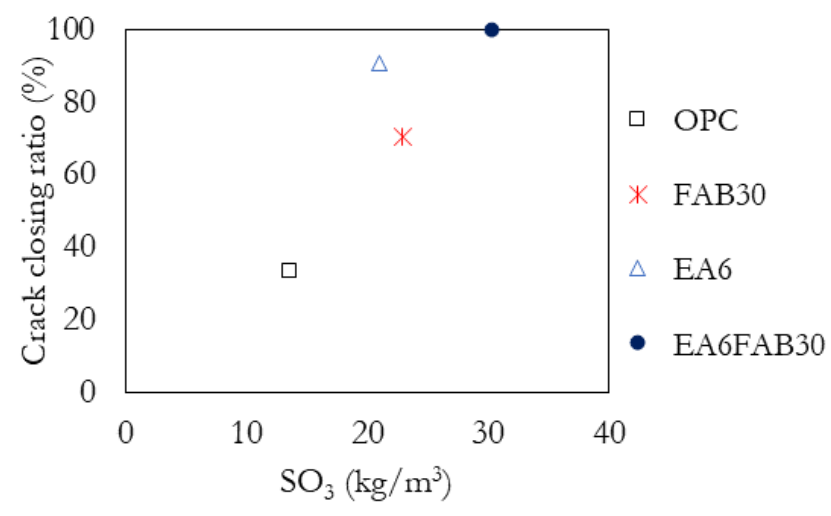

b) Relationship between $\mathrm{SO}_{3}$ content and the crack closing ratio of the tested mixtures

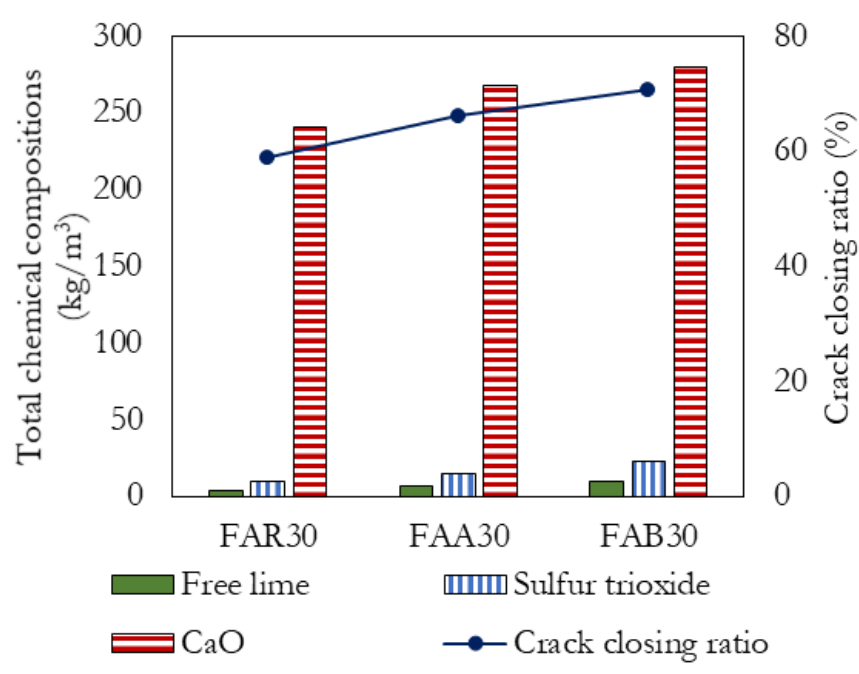

c) Relationship between total chemical composition in mixture and the crack closing ratio of fly ash mixtures at an age of 28 days

Fig. 8. Relationship between total chemical composition in mixture and result of the crack closing ratio of mixtures at an age of 28 days.

The $\mathrm{CaO}$, free lime, and $\mathrm{SO}_{3}$ contents in mortar mixture were calculated, to study the relationships between them and the self-healing behavior. They can be calculated by using Eqs. (3), (4), and (5).

$$
\begin{aligned}
& F=\frac{\left(\% F_{C} \times W_{C}\right)+\left(\% F_{e} \times W_{e}\right)+\left(\% F_{f} \times W_{f}\right)}{100} \\
& S=\frac{\left(\% S_{C} \times W_{C}\right)+\left(\% S_{e} \times W_{e}\right)+\left(\% S_{f} \times W_{f}\right)}{100} \\
& C=\frac{\left(\% C_{C} \times W_{C}\right)+\left(\% C_{e} \times W_{e}\right)+\left(\% C_{f} \times W_{f}\right)}{100}
\end{aligned}
$$

where $\quad F$ - Total free lime content in the mixture $\left(\mathrm{kg} / \mathrm{m}^{3}\right)$.

$\% \mathrm{~F}_{\mathrm{C}}, \% \mathrm{~F}_{\mathrm{e}}, \% \mathrm{~F}_{\mathrm{f}}$ - Free lime content in OPC I cement, EA, and FA, respectively ( $\%$ by weight).

$S$ - Total sulfur trioxide content in the mixture $\left(\mathrm{kg} / \mathrm{m}^{3}\right)$.

$\% \mathrm{~S}_{\mathrm{C}}, \% \mathrm{~S}_{\mathrm{e}}, \% \mathrm{~S}_{\mathrm{f}}$ - Sulfur trioxide content in OPC I cement, EA, and FA, respectively ( $\%$ by weight).

C - Total calcium oxide content in the mixture $\left(\mathrm{kg} / \mathrm{m}^{3}\right)$.

${ }_{0} \mathrm{C}_{\mathrm{C}}, \% \mathrm{C}_{\mathrm{e}}, \% \mathrm{C}_{\mathrm{f}}-$ Calcium oxide content in OPC I cement, EA, and FA, respectively (\% by weight).

$\mathrm{W}_{\mathrm{C}}, \mathrm{W}_{\mathrm{e}}, \mathrm{W}_{\mathrm{f}}$ - Weight of OPC I, EA, and FA in $1 \mathrm{~m}^{3}$ of mortar, respectively $\left(\mathrm{kg} / \mathrm{m}^{3}\right)$.

Figure 8 shows the relationship between the targeted oxide compound $\left(\mathrm{CaO}\right.$, free lime, and $\left.\mathrm{SO}_{3}\right)$ and the crack closing ratio of samples at an age of 28 days. The correlation between the total amount of free lime in the mixture and the crack closing ratio is illustrated in Fig. 8(a). The more the amount of free lime content, the higher the crack closing ratio. The figure shows a good relationship between the free lime content and the crack closing ratio. The presence of lime leads to the formation of colloidal ettringite, which can result in a large expansion of the whole system [23]. In Fig. 8(b), the correlation between total $\mathrm{SO}_{3}$ content in the mixture and the crack closing ratio is shown. Similarly, the larger $\mathrm{SO}_{3}$ content in the mixture enhances the crack closing ability. The EA6 mixture contains a smaller amount of $\mathrm{SO}_{3}$ but its crack closing ratio is higher than that of the FA30 mixture because both the free lime content and the $\mathrm{SO}_{3}$ content affect crack healing. The EA6 mixture contains a smaller amount of $\mathrm{SO}_{3}\left(1.89 \mathrm{~kg} / \mathrm{m}^{3}\right.$ of mortar) but a higher amount of free lime $\left(2.5 \mathrm{~kg} / \mathrm{m}^{3}\right)$ when compared to the FAB30 mixture, leading to a better self-healing ability for the EA6 mixture. Nawaz et al., [24] investigated the behavior of the expansion of concrete with different types of FA. They considered the $\mathrm{CaO}$, free lime, and $\mathrm{SO}_{3}$ contents. In their report, they confirmed that fly ashes containing a higher amount of $\mathrm{SO}_{3}$ showed higher expansion due to the internal sulfate from ettringite formation. 

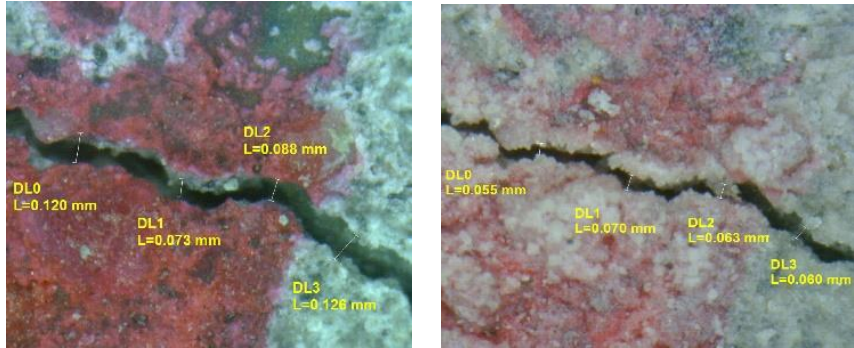

Initial age (3 days)

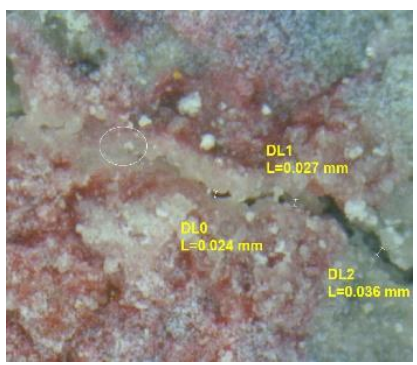

56 days of age

(a) EA6 mortar (in water curing conditions)

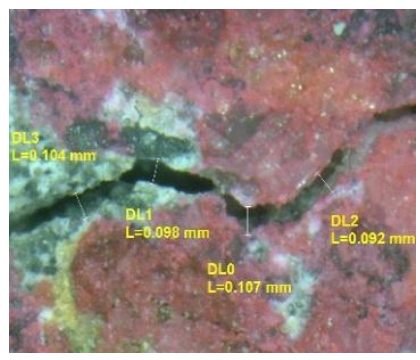

Initial age (3 days)

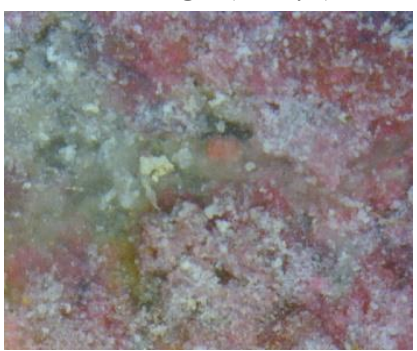

56 days of age
91 days of age

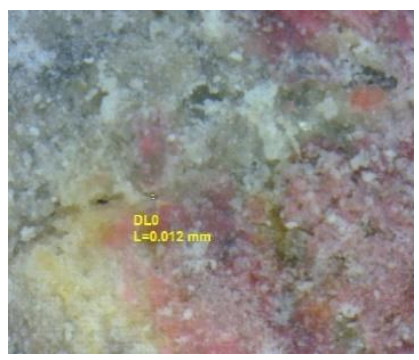

28 days of age

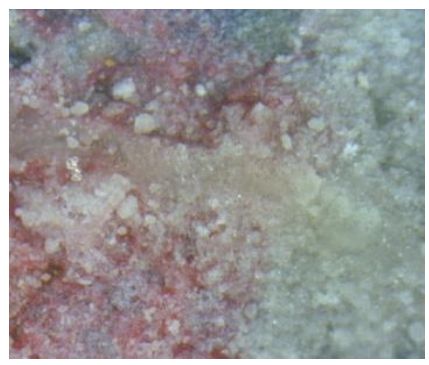

28 days of age

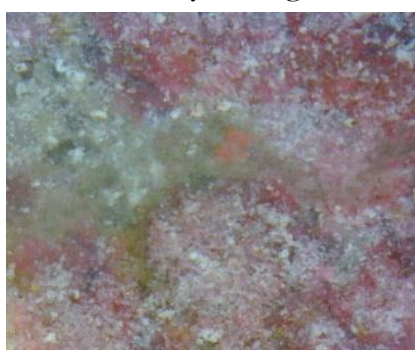

91 days of age (b) EA6FAB30 mortar (in water curing conditions)

Fig. 9. Crack closing of mortars at the initial age (3 days), and at 28, 56, and 91 days of age (initial surface crack width $=0.1 \mathrm{~mm}$ ) in water curing conditions.

In Fig. 8(c), the correlation between $\mathrm{CaO}$, free lime, and $\mathrm{SO}_{3}$ content in the mixtures and the crack closing ratio of non-EA mixtures with different types of fly ash is illustrated.

To compare only the effect of fly ash types, only the mixtures without EA but with different types of fly ash are considered in Fig. 8(c). It is seen in Fig. 8(c) that the higher the contents of $\mathrm{CaO}$, free lime, and $\mathrm{SO}_{3}$ in the fly ash, the higher the crack closing ratio. This indicates that FA containing higher $\mathrm{CaO}$, free lime, and $\mathrm{SO}_{3}$ contents is more effective for improving the self-healing ability. It is evident that the effectiveness of crack closing is different for mortar samples with different types of fly ash. The high $\mathrm{CaO}-\mathrm{SO}_{3}$ - free lime fly ash (FAB) provides the highest surface crack closing speed. In this study, fly ash type $\mathrm{B}(\mathrm{FAB})$ contains the highest contents of calcium oxide, sulfur trioxide, and free lime, followed by fly ash type A (FAA). Fly ash type R (FAR) contains the smallest amounts of those compounds.

Figure 9 shows pictures of surface crack healing of the tested samples. By using a Dino microscope device, the surface crack width can be clearly observed and measured. Figure 9(a) illustrates the crack closing images of the expansive mortar sample at the age of crack initiation (3 days of age), and at 28, 56, and 91 days of age (initial surface crack width $=0.1 \mathrm{~mm}$, cured in water). Figure 9(b) shows the crack closing images of the expansive mortar sample with fly ash type B at the age of crack initiation ( 3 days of age), and at 28, 56, and 91 days of age (initial surface crack width $=0.1 \mathrm{~mm}$, cured in water). It clearly illustrates that fly ash type B remarkably enhances the healing ability of expansive mortar, as previously mentioned.

In summary, the self-healing ability of mortar samples is improved significantly when using expansive additive and fly ash with high contents of $\mathrm{CaO}, \mathrm{SO}_{3}$, and free lime. These compositions demonstrate a major role in the self-healing process. During the hydration reaction, expansive products are formed. As a result, a crack is filled by these expansive products, especially ettringite.

\subsection{Effects of Bottom Ash}

Figure 10 illustrates the crack closing ratios of samples with and without bottom ash for up to 91 days. The crack closing ratios of OPC mortars with and without BA, and fly ash (FAB) mortars with and without BA, are illustrated in Fig. 10(a). Fig. 10(b) shows the crack closing ratios of the expansive mortars with and without $\mathrm{BA}$, and expansive mortars containing $\mathrm{FAB}$ with and without BA. It was found that, the effects of FA on OPC mortar and expansive mortar gave the same tendency in air curing conditions as that in water curing conditions. Figure 10(a) indicates that fly ash sample (FAB30) heals cracks faster than the OPC sample, and the crack closing ratios of both the OPC sample and the fly ash sample are much improved with the use of BA. At the age of 91 days, the crack closing ratio of OPCBA10 is $40 \%$ while the ratio of the OPC sample is only $30 \%$. Also, the crack closing ratio of FAB30BA10 is $51 \%$ while that of FAB30 is $47 \%$. Figure 10 (b) shows that expansive mortar with BA heals cracks faster than expansive mortar without $\mathrm{BA}$. With the IC by $\mathrm{BA}$, the crack closing ratio of EA6BA10 mixture is $61 \%$, which is $4 \%$ higher than that of the EA6 mixture. The crack closing ratio of the EA6FAB30 mixture is $61 \%$, while that of the EA6FAB30BA10 mixture is higher at $68.5 \%$ at an age of 91 days. 


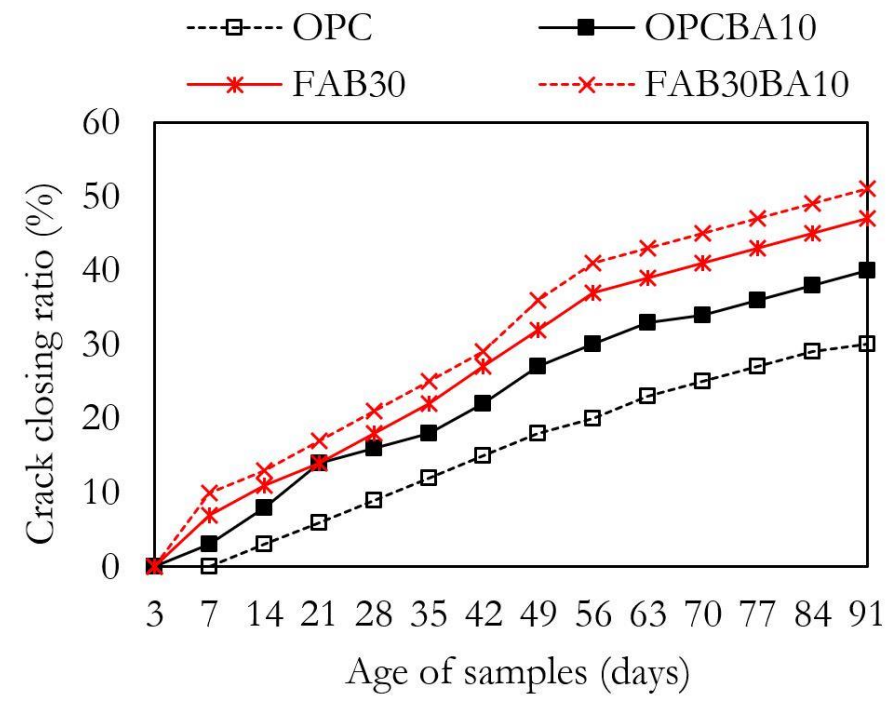

a) OPC mortar and fly ash mortar with and without BA

Fig. 10. Crack closing ratio of mortars (in air curing conditions).

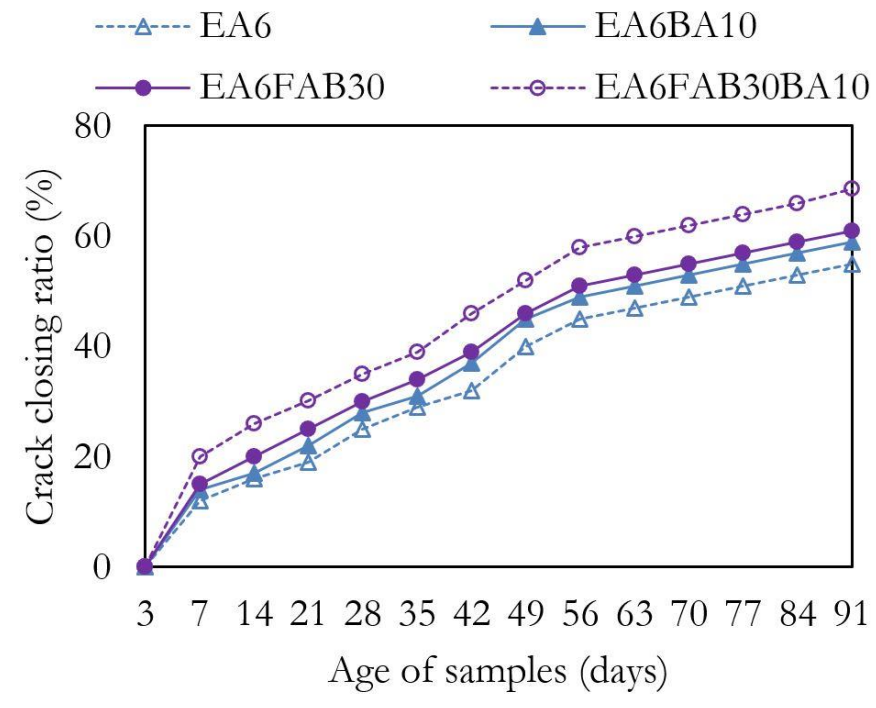

(b) Expansive mortar with and without BA

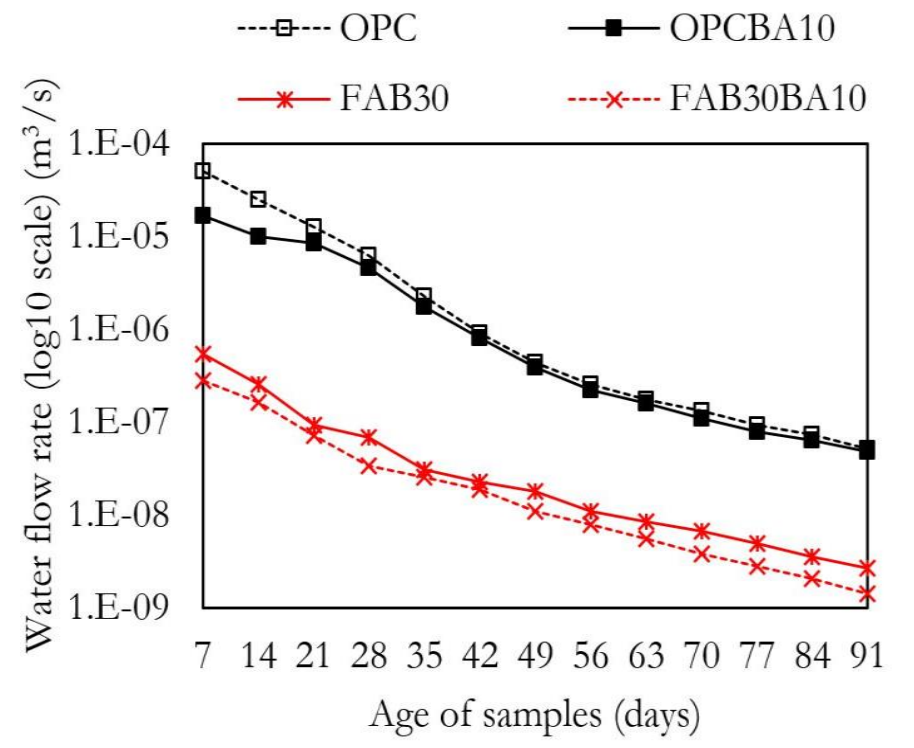

(a) OPC mortar and fly ash mortar with and without BA Fig. 11. Water flow rate of mortars (in air curing conditions).

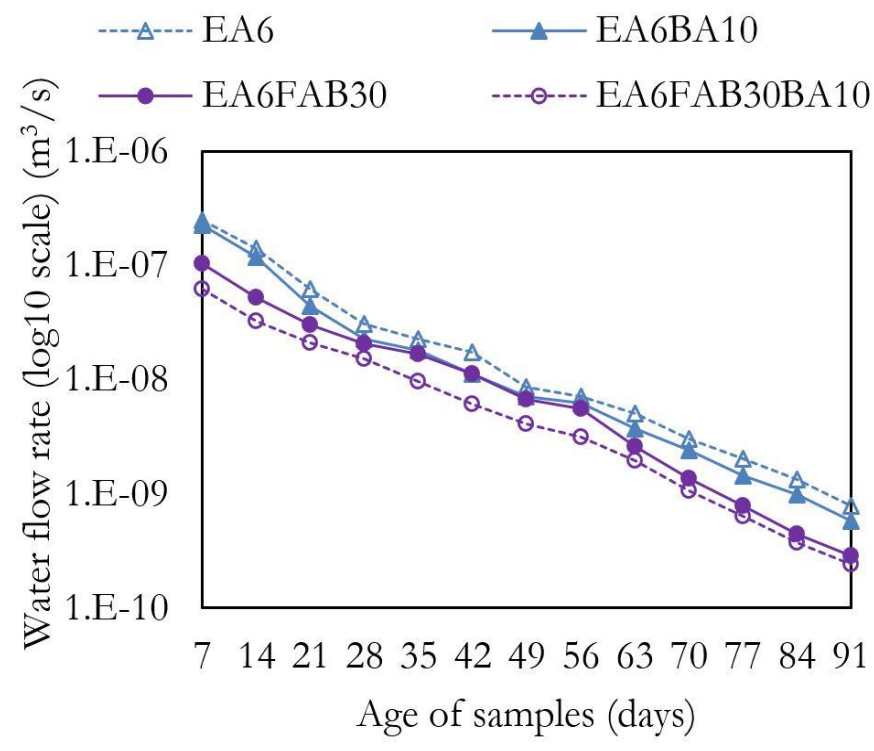

(b) Expansive mortars with and without BA
Figure 11 describes the flow rates of samples with and without $\mathrm{BA}$ at an age of 91 days. The effects of $\mathrm{BA}$ on the water flow rates of OPC and fly ash (FAB) mortars are shown in Fig. 11(a). The water flow rate of OPCBA10 mixture is smaller than that of the OPC mixture, and the flow rate of the FAB30BA10 mixture is smaller than the flow rate of the FAB30 mixture. This means that the S-H ability of samples with $\mathrm{BA}$ is better than that of samples without BA. In Fig. 11(b), the effects of $\mathrm{BA}$ on water flow rates of expansive mortars (with and without FA) are illustrated. Similarly, the expansive mortar with $\mathrm{BA}$ shows a lower water flow rate value.

Some pictures of surface crack healing of tested samples with and without BA are shown in Fig. 12(a), Fig. 12(b), Fig.12(c), and Fig. 12(d). Figure 12(a) and Figure 12(b) illustrate the crack closing images of the expansive OPC mortar samples, with and without BA at the age of crack initiation ( 3 days of age), and at 28,56 , and 91 days of age (initial surface crack width $=0.1 \mathrm{~mm}$, cured in air). Figure 12(c) and Figure 12(d) show the crack closing images of the expansive fly ash mortar samples with and without BA at the age of crack initiation (3 days of age), and at 28,56, and 91 days of age (initial surface crack width is $0.1 \mathrm{~mm}$, cured in air). This shows that the use of $\mathrm{BA}$ is effective in both expansive mortars, with and without FA.

The positive effects of $\mathrm{BA}$ are recorded in all cases of mixture and age due to the action of IC. When used in the mortars, the pre-soaked BA contains a high amount of water. In the long term, it provides water for continuous hydration and other reactions in the mortars. Normal water curing methods supply water to the concrete surface, but the water curing is unable to reach the inner part of the concrete. 


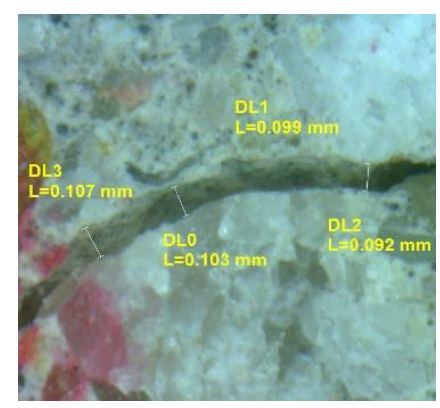

Initial age (3 days)

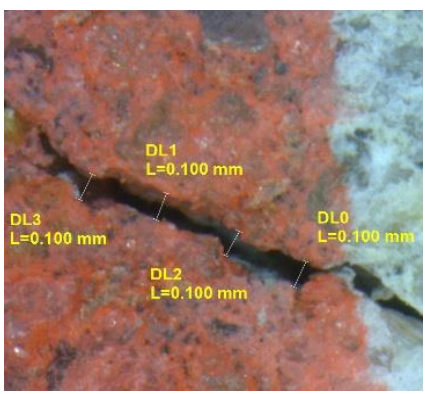

Initial age (3 days)

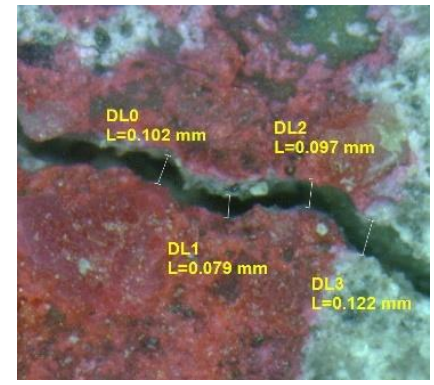

Initial age (3 days)

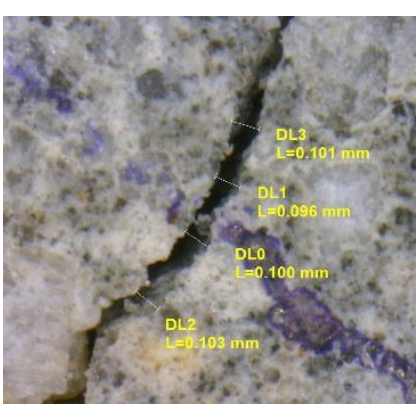

Initial age (3 days)

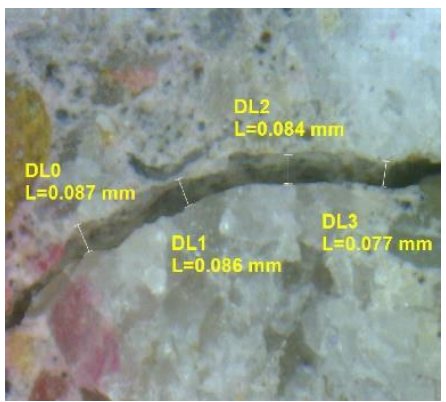

28 days of age

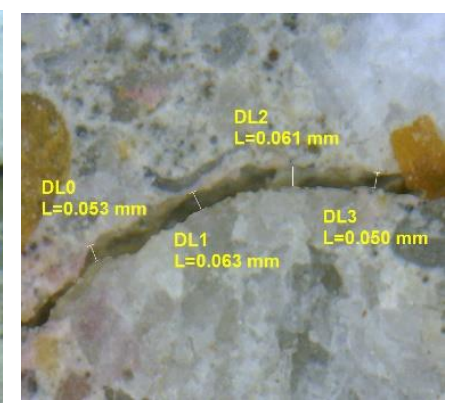

56 days of age

(a) EA6 mortar (in air curing conditions)
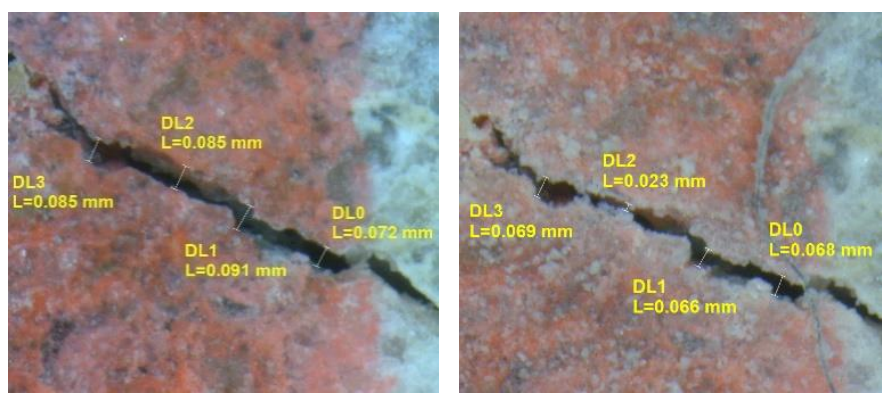

56 days of age

28 days of age

(b) EA6BA10 mortar (in air curing conditions)
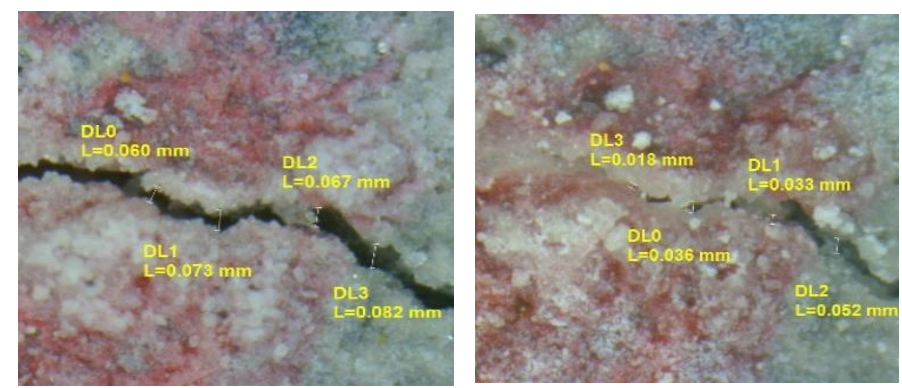

56 days of age

28 days of age

(c) EA6FAB30 mortar (in air curing conditions)
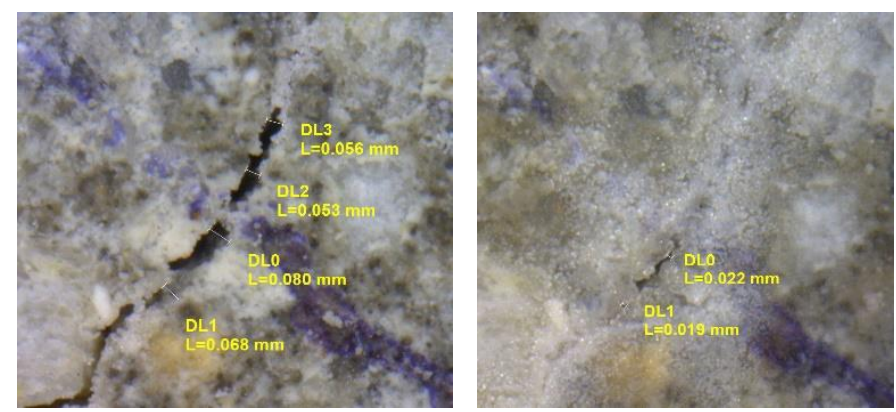

56 days of age

28 days of age

(d) EA6FAB30BA10 mortar (in air curing conditions)

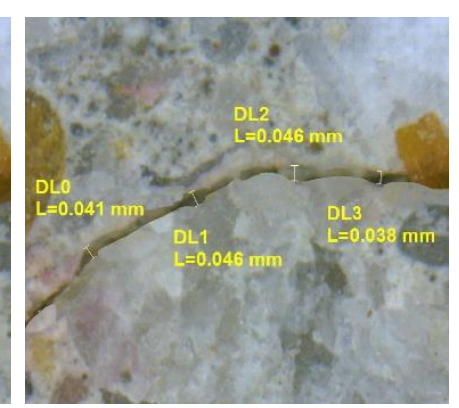

91 days of age

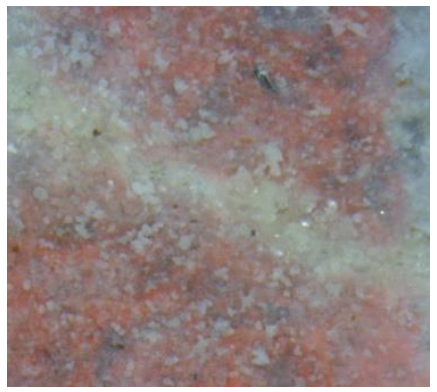

91 days of age

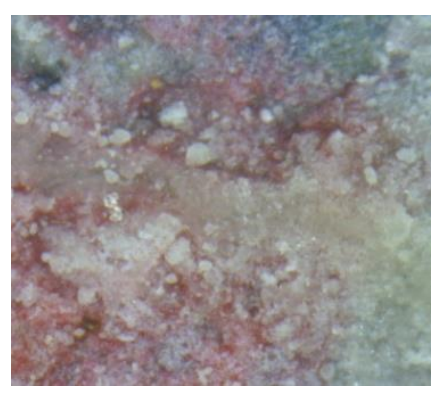

91 days of age

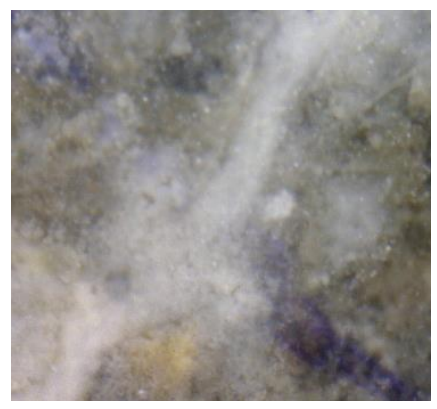

91 days of age

Fig. 12. Crack closing of mortars at the initial age (3 days), and at 28, 56, and 91 days of age (initial surface crack width $=0.1 \mathrm{~mm})$ in air curing conditions. 


\section{Conclusions}

Based on the test results, the following conclusions are obtained:

1) The self-healing $(\mathrm{S}-\mathrm{H})$ behavior of concrete can be quantitatively estimated from the crack-closing ratio and the water flow rate.

2) The crack filling by the hydration products, especially ettringite, is the major mechanism of the S-H ability.

3) The S-H ability of mortar was dramatically enhanced with the use of an expansive agent. The use of $6 \%$ EA in the binders sharply improved the performance of the S-H ability.

4) The S-H ability of mortar samples was improved significantly when using FA. The use of $30 \%$ FA led to the enhancement of the $\mathrm{S}-\mathrm{H}$ ability of the tested mortars. With the same amount of fly ash:

- the effectiveness of FA type on the S-H ability of mortar (from low to high) is in the following order: low $\mathrm{CaO}$ fly ash (FAR), high $\mathrm{CaO}$ fly ash (FAA), high $\mathrm{CaO}$-free lime- $\mathrm{SO}_{3}$ fly ash (FAB); - the effectiveness of FA on the self-healing ability depends on the amount of total free lime and $\mathrm{SO}_{3}$. The higher the amount of free lime and $\mathrm{SO}_{3}$ in the mixture, the better the S-H ability.

5) FA, when used in combination with the EA in mortars, provided more effective self-healing performance than separately using EA or FA.

6) The use of $\mathrm{BA}$ at $10 \%$ replacement of fine aggregate as the internal curing agent improved the S-H ability of the tested mortars.

7) The combined use of FA and BA in both the OPC mortar and the expansive mortar led to a remarkable improvement in the $\mathrm{S}-\mathrm{H}$ behavior of mortars.

\section{Acknowledgement}

The authors would like to acknowledge the research support from the Siam Research and Innovation Co., Ltd.; the Center of Excellence in Material Science, Construction and Maintenance Technology, Thammasat University; and the Chair Professor Program (P-1952302), the National Science and Technology Development Agency (NSTDA), Thailand. The authors also would like to thank the Sirindhorn International Institute of Technology, Thammasat University for a scholarship and financial support for the first author.

\section{References}

[1] K. Sisomphon, O. Copuroglu, and E. A. B. Koenders, "Self-healing of surface cracks in mortars with expansive additive and crystalline additive," Cement and Concrete Composites, vol. 34, no. 4, pp. 566574, Apr. 2012.

[2] A. Hosoda, T. Kishi, H. Arita, and Y. Takakuwa, "Self-healing of crack and water permeability of expansive concrete," in First International Conference on
Self-Healing Materials, Noordwijk, Netherlands, 2007, pp. 18-20.

[3] T. H. Ahn and T. Kishi, "Crack self-healing behavior of cementitious composites incorporating various mineral admixtures," Journal of Advanced Concrete Technology, vol. 8, no. 2, pp. 171-186, 2010.

[4] D. Jaroenratanapirom and R. Sahamitmongkol, "Effects of different mineral additives and cracking ages on self-healing performance of mortar," in $6^{\text {th }}$ Annual Concrete Conference, Petchaburi, Thailand, 2010, pp. 551-556.

[5] S. Qian, J. Zhou, M. R. de Rooij, E. Schlangen, G. Ye, and K. van Breugel, "Self-healing behavior of strain hardening cementitious composites incorporating local waste materials," Cement and Concrete Composites, vol. 31, no. 9, pp. 613-621, Oct. 2009.

[6] C. Edvardsen, "Water permeability and autogenous healing of cracks in concrete," ACI Materials Journal, vol. 96, no. 4, pp. 448-454, 1999.

[7] H. W. Reinhardt and M. Jooss, "Permeability and self-healing of cracked concrete as a function of temperature and crack width," Cement and Concrete Research, vol. 33, no. 7, pp. 981-985, Ju., 2003.

[8] ACI Committee 308 and 213, "Report on internally cured concrete using prewetted absorptive lightweight aggregate," American Concrete Institute, 2013.

[9] R. Kasemchaisiri and S. Tangtermsirikul, "Properties of self-compacting concrete incorporating bottom ash as a partial replacement of fine aggregate," ScienceAsia, vol. 34, pp. 087-095, 2008.

[10]K. Hussain, P. Choktaweekarn, and S. Tangtermsirikul, "Effect of bottom ash and mineral admixtures on the curing sensitivity of concrete," Research and Development Journal, vol. 22, no. 4, pp. 2533, Sep. 2011.

[11]P. Sutthiwarre, R. Sahamitmongkol, and S. Tangtermsirikul, "Effect off internal curing on expansion and shrinkage of expansive concrete," Thammasat International Journal of Science and Technology, vol. 20, no. 4, Dec. 2015.

[12] M. Wyrzykowski, S. Ghourchian, S. Sinthupinyo, N. Chitvoranund, T. Chintana, and P. Lura, "Internal curing of high performance mortars with bottom ash," Cement and Concrete Composites, vol. 71, pp 1-9, 2016.

[13]D. Cusson and T. Hoogeveen, "Internal curing of high-performance concrete with pre-soaked fine lightweight aggregate for prevention of autogenous shrinkage cracking," Cement and Concrete Research, vol. 38, no. 6, pp. 757-765, Jun. 2008.

[14] T. J. Barrett, A. Miller, and W. J. Weiss, "Reducing shrinkage cracking with internal curing: From theory to practice," Indian Concrete Journal, vol. 88, pp. 61-77, Apr. 2014.

[15] N. Lathsoulin, P. Sancharoen, and S. Tangtermsirikul, "Development of method to determine water retainability of porous fine aggregate," in $10^{\text {th }}$ 
International Symposium in Science and Technology, Bangkok, Thailand, 2015, pp. 194-199.

[16] Report on Water Permeability of Hardened Concrete, Western Australian Standard WA625.1, Main Road Western Australia, 1998.

[17] Report on Testing Concrete; Testing of Fresh Concrete, German National Standard DIN 1048.1, Building and Civil Engineering Standards Committee, 1991.

[18] S. Tangtermsirikul, Durability and Mix Design of Concrete, 1st ed. Printing House of Thammasat University, Rangsit Campus, Aug. 2003.

[19] ACI Committee 223, Guide for the Use of ShrinkageCompensating Concrete. American Concrete Institute, 2010.

[20] A. Hosoda, T. Higuchi, M. Eguchi, H. Yoshida, and H. Aoki, "Self healing of longitudinal cracks in utility concrete pole," Journal of Advanced Concrete Technology, vol. 10, no. 8, pp. 278-284, Aug. 2012.

[21]T. Danner, U. H. Jakobsen, and M. R. Geiker, "Mineralogical sequence of self-healing products in cracked marine concrete," Minerals, vol. 9, no. 5, pp. 1-20, May 2019.
[22] T. B. T. Nguyen, R. Chatchawan, W. Saengsoy, S. Tangtermsirikul, and T. Sugiyama, "Influences of different types of fly ash and confinement on performances of expansive mortars and concretes," Construction and Building Materials, vol. 209, pp. 176186, Jun. 2019.

[23] P. K. Mehta, "Mechanism of expansion associated with ettringite formation," Cement and Concrete Research, vol 3, no. 1, pp. 1-6, Jan. 1973.

[24] A. Nawaz, P. Julnipitawong, P. Krammart, and S. Tangtermsirikul, "Effect and limitation of free lime content in cement-fly ash mixtures," Construction and Building Materials, vol. 102, no. 1, pp. 515-530, Jan. 2016.

[25]T. B. T. Nguyen, W. Saengsoy, and S. Tangtermsirikul, "Influence of bottom ashes with different water retainabilities on properties of expansive mortars and expansive concretes," Engineering Journal, vol. 23, no. 5, pp. 108-123, Sep. 2019. 


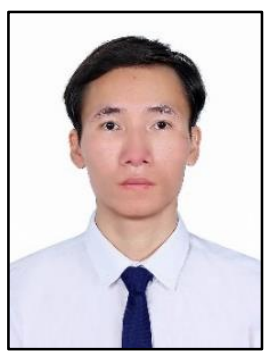

Nghia D. Tran was born in Nam Dinh, Vietnam in 1990. He received the B.Eng. degree in Civil Engineering from Hanoi Architectural University, Hanoi, Vietnam and a M.Sc. degree in Civil Engineering from the Sirindhorn International Institute of Technology, Thammasat University, Thailand, in 2019.

From 2013 to 2014, he worked as a Site Engineer for the Vietnam Institute for Building Science and Technology (IBST). From 2014 to 2015, he worked as a Quality Control Engineer for Viglacera Corporation - JSC. Since 2016, he has been a graduate student and teaching assistant at the Sirindhorn International Institute of Technology, Thammasat University. Since 2019, he has been a Field Engineer at the Project and Proposal Department in TTCL Public Company Limited, Bangkok, Thailand. $\mathrm{He}$ is the author of 2 articles. His research interests include the application of industrial waste for the production of building materials, durability of concrete, and self-healing ability of cement-based materials.

Mr. Tran was awarded the first prize of "Sustainable Construction Sector" of the Holcim Prize, a certificate of merit by the Vietnam Youth Union for "Create works, theory, initiative to join $6^{\text {th }}$ National outstanding Innovative product contest in 2013" in the Vietnam National Youth Creation Festival in 2013, and the Excellent Foreign Student (EFS) scholarship during 2015 to 2017 from the Sirindhorn International Institute of Technology (SIIT), Thammasat University. He was awarded the Best Presentation at the $3^{\text {rd }}$ International Symposium on Concrete and Structures for Next Generation in 2018.

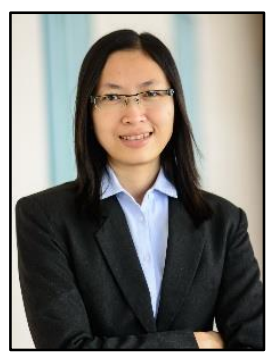

Warangkana Saengsoy was born in Phrae, Thailand in 1979. She received B.Eng. and M.Sc. degrees in Civil Engineering from the Sirindhorn International Institute of Technology, Thammasat University, Thailand and a Ph.D. in Resources and Eco-materials Engineering from Hokkaido University, Japan, in 2008.

Since 2009, she has been a research faculty member (currently Research Assistant Professor) at the Construction and Maintenance Technology Research Center (CONTEC), Sirindhorn International Institute of Technology (SIIT), Thammasat University. She is the author of 65 articles. Her research interests include cement chemistry, hydration reactions and microstructure of cementitious systems, chemical and microstructural analysis of hardened concrete, utilization of pozzolans and ecomaterials in concrete, and durability of concrete. She is a committee member of the Thailand Concrete Association (TCA) and a technical committee member of the Asian Concrete Federation (ACF).

Dr. Saengsoy received a Ministry of Education, Culture, Sports, Science and Technology of Japan (MEXT) scholarship during 2005 to 2008, Outstanding Young Researcher Award for researchers from Thammasat University in 2012, ACF Best Paper Award in 2014, and Outstanding Researcher Award from Thammasat University in 2014, 2017, 2018.

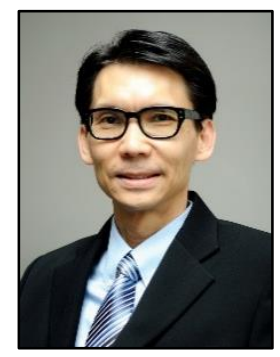

Somnuk Tangtermsirikul was born in Bangkok, Thailand in 1962. He obtained his B.Eng. in Civil Engineering from Chulalongkorn University, Thailand, and both the M.Eng. and D.Eng. in Civil Engineering from the University of Tokyo, Japan.

Since 2007, he has been the Head of the Construction and Maintenance Technology Research Center (CONTEC). From 2012 to 2018, he was the Director of SIIT. He is the author of more than 200 articles. His research areas include modeling of concrete behavior, durability evaluation and service life design of concrete structures, high performance cementitious based materials, special concrete, use of wastes and recycled materials in cement and concrete, and the repair, maintenance, and assessment of concrete structures. He is an Advisor of the Thailand Concrete Association, VicePresident (Technical) of the Asian Concrete Federation (ACF), and on the Advisory Board of the Advanced Concrete Technology International Journal, Editorial Board of the Journal of Asian Concrete Federation, and the ASEAN Engineering Journal, and the Chairman of the Editorial Board of the Journal of Thailand Concrete Association.

Prof. Tangtermsirikul received various awards such as an Outstanding Technologist Award from the Foundation for the Promotion of Science and Technology under the Patronage of H.M. the King in 2002; National Distinguished Researcher, National Research Council in 2013; and Excellent Research Award, National Research Council in 2016. 